\section{ACRL SECTION AND SUBSECTION COMMITTEE CHAIRMEN}

\section{COLLEGE LIBRARIES SECTION}

Nominating Committee: Richard Quick, Director of Libraries, State University College, Geneseo, N.Y. 14454.

Steering Committee: John E. Scott, Head Librarian, West Virginia State College, Institute 25112.

Committee on Non-Western Resources: Mother Elizabeth O'Connor, Librarian, Manhattanville College of the Sacred Heart, Purchase, N.Y. 10577.

\section{JUNIOR COLLEGE LIBRARIES SECTION}

Bibliography Committee: Harold Young, Director, Learning Resource Center, Washtenaw Community College, P.O. Box 345, Ann Arbor, Mich. 48107.

Instruction and Use Committee: Martin S. Gaskin, Director of Library Services, St. Clair County Community College, 323 Erie St, Port Huron, Mich. 48060.

Committee on Instructional Materials Center: Alfredo de los Santos, Jr., Dean of Instructional Resources, Northampton County

\section{OTTO HARRASSOWITZ Library Agency WIESBADEN - GERMANY}

\author{
Direct service \\ on all German language \\ books and periodicals
}

Orders and inquiries are invited on both new and out-of-print material

Please request information about our blanket order service and dealer's selection program

Farmington Plan agent for West and East Germany
Area Community College, 3855 Green Pond Rd., Bethlehem, Pa. 18017.

Nominating Committee: David Reich, Associate Director of Public Services, Dallas (Tex.) Public Library, 1954 Commerce St., 75201 .

Preconference Planning Committee: Mrs. Louis Giles, Associate Dean, Learning Resources Center, Orchard Ridge Campus, Oakland Community College, Farmington, Mich. 48024.

Ad Hoc Committee to Revise the JCLS Bylaws: Mrs. Ruth M. Christensen, S.W. Museum, Highland Park, Los Angeles, Calif.

Special Projects Committee: Alice B. Griffith, Library Director, Mohawk Valley Community College, 1101 Sherman Dr., Utica, N.Y. 13501.

Ad Hoc Committee to Study the Needs of Private Junior College Libraries: Donald Webster, Librarian, Cazenovia (N.Y.) Junior College, 13035.

\section{RARE BOOKS SECTION}

Nominating Committee: Herbert T. F. Cahoon, Director, Library Services, Pierpont Morgan Library, 33 E. 36th St., New York 10016 .

Preconference Local Arrangements Committee: Gloria A. Francis, Chief, Gifts \& Rare Book Division, Public Library, Detroit, Mich. 48202 .

Preconference Program Committee: Robert J. Adelsperger, Special Collections Librarian, University of Illinois, The Library, P.O. Box 8198, Chicago, IIl. 60680.

Ad Hoc Committee on Manuscript Collections: Mrs. Arline Custer, Editor, NUCMC, Descriptive Cataloging Division, Library of Congress, Washington, D.C. 20540.

Standards Subcommittee: Howard Applegate, Assistant Director in Charge of Special Collections and Development, Syracuse (N.Y.) University Library, 13210.

Work Manual Subcommittee: Ruth Salisbury, Coordinator, Department of Special Collections, University of Pittsburgh ( $\mathrm{Pa}$.) Libraries, 15213.

\section{SUBJECT SPECIALISTS SECTION}

Nominating Committee: Judith A. Hoffberg, Fine Arts Librarian, Furness Building, University of Pennsylvania, Philadelphia 19104.

Ad Hoc Committee to Revise the SSS Bylaws: Marcia J. Miller, Division of Cataloging and Acquisitions, United States Department of Labor, Washington, D.C. 20210.

Agricultural and Biological Sgience SubSECTION

Nominating Committee (1970): Elsie Bergland, Biomedical Sciences Librarian, Colorado State University, Fort Collins 80521. 
Nominating Committee (1971): Walter Shelton, Assistant Librarian, John Crerar Library, 35 W. 33rd St., Chicago, Ill. 60616.

Eunice Rockwell Oberly Memorial Award Committee: Fleming Bennett, Librarian, Hume Library, University of Florida, Gainesville 32603.

\section{Art Subsection}

Nominating Committee: Herbert G. Scherer, Art Librarian, University of Minnesota, 104 Jones Hall, Minneapolis 55455.

\section{Law and Political Science Subsection}

Nominating Committee: J. Myron Jacobstein, Law Librarian, Stanford (Calif.) University Library, 94304.

Committee on Model Law Collections: Roy Mersky, Librarian and Director of Research, University of Texas School of Law, 2500 Red River, Austin 78705.
Slavic and East European Subsection

Nominating Committee: Jerzy J. Maciuszko, Slavic Department, Alliance College, Cambridge Springs, Pa. 16403.

\section{UNIVERSITY LIBRARIES SECTION}

Committee on Extension Library Service: Frank C. MacDougall, Librarian, Continuing Education Library, Michigan State University, East Lansing 48823.

Nominating Committee: Howard Rovelstad, Director of Libraries, University of Maryland, College Park 20742.

Steering Committee: Roscoe Rouse, University Librarian, Oklahoma State University, Stillwater 74074 .

Urban Universities Library Committee: Harold B. Schell, Assistant Director of Libraries, University of Pittsburgh (Pa.), 15213.

\section{From Inside the DLP}

\section{By Dr. Katharine M. Stokes}

College and University Library Specialist, Library Planning and Development Branch, Division of Library Programs, Bureau of Adult, Vocational, and Library Programs, U.S. Office of Education, Washington, D.C. 20202.

Do you remember assembling, in the summer of 1967, statistics to fill in the blanks of the Office of Education's College and University Library Resources and Facilities Higher Education General Information Survey forms? It called for a lot of figures on the percentage of your collection devoted to specified areas and on the square feet assigned to your libraries. If you've been wondering about whatever hapfjened to those painfully compiled totals, look at Tables 3,4 , and 5 of the latest publication released by the Library Surveys Branch of the National Center for Educational Statistics, $\mathrm{Li}$ brary Statistics of Colleges and Universities: Data for Individual Institutions, Fall 1967, (OE-15023-67), edited by Dr. Bronson Price. A copy was sent to each institution of higher education. Additional copies may be obtained from the Superintendent of Documents, G.P.O., for $\$ 2.50$.

You will recall that in 1968 only the Preliminary Report on Academic Libraries, 196667 was published; that report contained partial data for a sample of 395 of the 2,157 separate institutions and five joint libraries (serving two or more institutions) which are included in the Fall 1967 issue. Although two years have passed since the space figures in this issue were submitted, they are probably still valid for most of the libraries.

The 1967 space figures for libraries in the same state, or for libraries serving student bodies of similar size and makeup, will be worth close scrutiny, especially those of the junior and community colleges, which show wide divergences. In Table $\mathbf{5}$, where the data are averaged per student, the square footage varies from one to fourteen for community colleges in one state studied.

The Higher Education Facilities Act funds are assisting many new junior colleges, some of them through their involvement in Model Cities programs. Grants are made from the federal allotments to the states. The State Commissions, established to administer state plans, receive applications and assign priorities to eligible projects. The priority list is submitted to the Office of Education's Regional Office for review, and those projects which satisfy eligibility requirements are then approved by the Regional Director of Higher Education.

Since 1966, over 800 library facilities have been partially funded under the Higher Education Facilities Act. Of the 137 buildings that Dr. Jerrold Orne noted in his Library Journal articles in the December 1 issues of 1967 and 1968 , as being occupied or dedicated in those years, only twenty-three had not been assisted by federal aid, so probably a couple of hundred privately funded libraries are either completed or under construction in addition to the 800 that received HEFA grants. 